\title{
Pengembangan Potensi Gulma Kirinyuh Dan Limbah Pertanian Sebagai Pupuk Organik Alternatif Di Nagari Palaluar Kecamatan Koto Vii Kabupaten Sijunjung Sumatera Barat
}

\author{
Riza Syofiani, Santi Diana Putri \\ Program Studi Agroteknologi, STIPER Sawahlunto Sijunjung \\ Email : rizasyofiani14@gmail.com
}

\begin{abstract}
Nagari Palaluar, Koto VII Subdistrict, Sijunjung Regency has an area of 5,47.17 ha. . The farmer groups in Palaluar Nagari who are partners are the Gelugur Jaya Farmers Group and the Minang Farmers Group. The dominant farming effort was cultivated by the Gelugur Jaya farmer group, namely rice. In rice cultivation, farming communities in this group every planting season always use artificial fertilizers. Even though rice harvested straw can be reused as an alternative source of organic fertilizer. Most of the agricultural waste, namely rice straw, is simply burned so that it can increase global warming. There are quite a lot of weeds in empty land and on the roadside in the Gelugur Jaya farmer group area. However, farmers have never used it as a source of organic material. Then the Minang farmer group built, the dominant farming business was rice and corn and cocoa plants. Cocoa plants produce a lot of waste, that is, cocoa skin waste is left piling around the land. Therefore it is necessary to process agricultural wastes. The objectives of this PKM program are (1) to increase the knowledge of partner group farming communities about the potential for sugar weeds and agricultural waste as alternative organic fertilizers in reducing the use of artificial fertilizers (2) provide examples of the application of rice cultivation techniques to the use of alternative organic fertilizers, namely weeds and agricultural waste to reduce the application of artificial fertilizers and increase the yield of rice crops. The method of carrying out activities is carried out by lecture, question and answer, demonstration, training (practice), assignment, mentoring and evaluation. The results expected from the implementation of the program are: (1) farmers' knowledge will increase about the importance of making and the potential of sugar weeds and agricultural waste as a source of alternative organic fertilizers to reduce the application of artificial fertilizers and increase rice production. (2) the farming community of the partner group is willing and able to imitate the application of rice cultivation techniques by utilizing sugar weeds and agricultural waste as an alternative organic fertilizer.
\end{abstract}

Keywords : kirinyuh, agricultural waste, organic fertilizer, rice production

\begin{abstract}
ABSTRAK
Nagari Palaluar, Kecamatan Koto VII, Kabupaten Sijunjung seluas 5.47,17 ha, yang memiliki kelompok Tani Gelugur Jaya dan Kelompok Tani Minang sebagai mitra. Usaha pertanian dominan dilakukan oleh kelompok tani Gelugur Jaya, yaitu padi. Dalam penanaman padi kelompok ini menggunakan pupuk buatan. Padahal jerami padi yang dipanen dapat digunakan kembali sebagai sumber alternatif pupuk organik. Sebagian besar limbah pertanian, yaitu jerami padi, dibakar begitu saja sehingga dapat meningkatkan pemanasan global. Ada cukup banyak gulma di tanah kosong dan di pinggir jalan di daerah kelompok tani Gelugur Jaya. Namun, petani tidak pernah menggunakannya sebagai sumber bahan organik. Kemudian
\end{abstract}


kelompok tani Minang dibangun, bisnis pertanian yang dominan adalah tanaman padi dan jagung dan kakao. Tanaman kakao menghasilkan banyak limbah, yaitu limbah kulit kakao dibiarkan menumpuk di sekitar tanah. Oleh karena itu perlu untuk mengolah limbah pertanian. Tujuan dari program PKM ini adalah (1) untuk meningkatkan pengetahuan komunitas petani kelompok mitra tentang potensi gulma gula dan limbah pertanian sebagai pupuk organik alternatif dalam mengurangi penggunaan pupuk buatan (2) memberikan contoh penerapan budidaya padi teknik penggunaan pupuk organik alternatif, yaitu gulma dan limbah pertanian untuk mengurangi aplikasi pupuk buatan dan meningkatkan hasil panen padi. Metode pelaksanaan kegiatan dilakukan dengan ceramah, tanya jawab, peragaan, pelatihan (latihan), penugasan, pendampingan dan evaluasi. Hasil yang diharapkan dari implementasi program adalah: (1) pengetahuan petani akan meningkat tentang pentingnya membuat dan potensi gulma gula dan limbah pertanian sebagai sumber pupuk organik alternatif untuk mengurangi penerapan pupuk buatan dan meningkatkan beras produksi. (2) komunitas tani dari kelompok mitra bersedia dan mampu meniru penerapan teknik penanaman padi dengan memanfaatkan gulma gula dan limbah pertanian sebagai alternatif pupuk organik.

Kata kunci: kirinyuh, limbah pertanian, pupuk organik, produksi beras

\section{PENDAHULUAN}

Nagari Palaluar Kecamatan Koto VII Kabupaten Sijunjung memiliki luas wilayah 547,17 ha, pekarangan 37 ha, Tegalan/ Kebun 117,72 ha, kolam 5,22 ha, sawah 134,11 ha, hutan 241,12 ha dan tanah lainnya 12 ha. Nagari ini berada pada ketinggian 218 meter diatas permukaan laut dengan keadaan wilayah bergelombang, berbukit, dan datar. Nagari Palaluar memiliki batas-batas nagari sebagai berikut : Sebelah Barat berbatasan dengan Nagari Bukit Bual, Sebelah Timur berbatasan dengan Nagari Tanjung, Sebelah Utara berbatasan dengan Nagari Guguk dan Sebelah Selatan berbatasan dengan Nagari Limo Koto. Jarak tempuh dari Nagari Palaluar ke Ibu Provinsi $\pm 102,7$ $\mathrm{km}$, ke Ibu Kota $\pm 33,7 \mathrm{~km}$ dan ke Ibu Kecamatan 6,5 km. Nagari Palaluar memiliki jumlah penduduk sebanyak 3213 jiwa, yang terdiri dari 1091 kepala keluarga (KK). Jenis tanah di Nagari Palaluar pada umumnya adalah Podsolik Merah Kuning (PMK). Tipe iklim termasuk daerah yang beriklim tropis dengan suhu rata - rata $32^{\circ} \mathrm{C}$.

Nagari Palaluar memiliki beberapa kelompok tani diantaranya kelompok tani Gelugur Jaya dan kelompok tani Minang
Membangun. Usaha tani yang dominan di kelompok tani Gelugur Jaya yaitu tanaman pangan, dengan komoditi unggulan padi. Luas lahan yang dikelola kelompok ini \pm 25 ha. Dalam budidaya tanaman padi, masyarakat tani di kelompok ini menggunakan pupuk buatan. Ada beberapa hal yang menjadi kendala bagi masyarakat tani di kelompok ini dalam membudidayakan tanaman padi, yaitu keterbatasan modal petani dalam pengadaan pupuk buatan dan produksi padi sawah selalu menurun setiap tahunnya. Sehingga pemakaian pupuk buatan intensif dilakukan setiap musim tanam. Harga pupuk buatan semakin mahal dan bahkan langka.

Gulma kirinyuh terdapat cukup banyak pada lahan-lahan kosong dan di pinggir-pinggir jalan di wilayah kelompok tani Gelugur Jaya. Akan tetapi petani belum pernah memanfaatkannya sebagai sumber bahan organik ataupun sumber hara nitrogen (N) dan kalium (K). Dari beberapa penelitian yang telah dilakukan, gulma kirinyuh dapat dijadikan sumber bahan organik serta sumber hara terutama $\mathrm{N}$ dan K. Dilaporkan bahwa gulma kirinyuh dapat meningkatkan pertumbuhan dan hasil selada (Duaja, 2012). Selanjutnya, jerami 
hasil panen tanaman padi bisa dimanfaatkan kembali sebagai sumber pupuk organik alternatif. Pemanfaatan pupuk organik dapat mengurangi biaya produksi dalam pengadaan pupuk buatan yang harganya setiap tahun mengalami peningkatan.

Kemudian kelompok tani Minang Membangun, kelompok tani ini berdiri pada tahun 1982. Luas lahan yang dikelola kelompok ini yaitu \pm 22 ha. Usaha tani yang dominan yaitu tanaman pangan dengan komoditi unggulan tanaman padi dan jagung. Selain tanaman pangan, komoditi unggulan yang menjadi primadona dari sektor perkebunan pada kelompok tani Minang Membangun yaitu komoditi kakao. Luas lahan yang ditanami kakao di kelompok tani Minang Membangun \pm 10 ha. Tanaman kakao banyak menghasilkan limbah, limbah tersebut antara lain berupa daun guguran dan kulit buah. Tanaman kakao banyak menghasilkan limbah, limbah tersebut antara lain berupa kulit buah. Pengolahan limbah kulit kakao sangat perlu dilakukan dikarenakan tanaman kakao merupakan tanaman yang secara umum dimanfaatkan bagian bijinya saja. Setelah panen, jerami padi dan jerami jagung biasanya dibakar serta limbah tongkol jagung dan kulit jagung ditumpuk begitu saja setelah dipipil butirnya oleh masyarakat tani Minang Membangun.. Masyarakat tani di kelompok tani Minang Membangun tidak mengetahui bahwa limbah tongkol jagung dan kulit jagung dapat dijadikan pupuk organik. Oleh karena itu penggunaan pupuk organik merupakan suatu kebutuhan mendesak.

\section{BAHAN DAN METODE}

\subsection{Sosialisasi IPTEK}

Sosialisasi IPTEK ditujukan kepada masyarakat tani kelompok mitra, dan masyarakat tani lainnya yang berminat untuk mengikutinya. Sosialisasi IPTEK ini dilaksanakan dengan kerja sama Dinas Pertanian Kecamatan Koto VII. Tujuan kegiatan ini yaitu (1). Mensosialisasikan teknologi pengolahan kirinyuh dan limbah pertanian menjadi kompos kepada masyarakat tani kelompok mitra, dan masyarakat tani lainnya yang berminat untuk mengikutinya. (2) Memberikan gambaran mengenai pentingnya pengolahan kirinyuh dan limbah pertanian menjadi salah satu sumber pupuk organik untuk mengurangi aplikasi pupuk buatan, menjaga kelestarian lingkungan, dan meningkatkan produktifitas tanah dan hasiltanaman yang dibudidayakan khususnya tanaman padi. Mendiskusikan teknologi yang tepat guna dan murah untuk dikembangkan dan diterapkan bagi masyarakat tani kelompok mitra, dan masyarakat tani lainnnya. (4) Melatih masyarakat tani kelompok mitra, dan masyarakat tani lainnya dalam penerapan teknologi hingga melaksanakan dengan baik dan benar serta membuktikan kepada khalayak sasaran manfaat teknologi dalam meningkatkan produktifitas.

\subsection{Ceramah dan diskusi}

Ceramah dan diskusi dilakukan untuk menjelaskan kepada mitra berbagai hal mengenai IPTEK yang akan diterapkan antara lain

a. Potensi gulma kirinyuh sebagai pupuk organik alternatif

b. Pengolahan limbah bahan organik

c. Cara pengaplikasian yang tepat ke tanaman yang dibudidayakan

\subsection{Demonstrasi cara}

1. Demonstrasi cara pencacahan atau perajangan kirinyuhdan limbah pertanian dengan mesin chopper.

2. Demonstrasi cara pembuatan kompos kirinyuh dan limbah pertanian

\subsection{Demonstrasi hasil}

1. Demonstrasi pencacahan atau perajangan kirinyuh, limbah kulit 
kakao, jerami padi dengan mesin chopper.

2. Demonstrasi pembuatan kompos kirinyuh, limbah kulit kakao, jerami padi, pupuk kandang

3. Demonstrasi aplikasi kompos kirinyuh dan limbah pertanian ke tanah

\subsection{Pembimbingan dan pendampingan}

Setelah dilakukan demonstrasi cara dan hasil, pembimbingan dan pendampingan masih tetap dilakukan ke masyarakat tani kelompok mitra.

\section{HASIL DAN PEMBAHASAN}

\subsection{Pengetahuan kelompok mitra tentang pentingnya bahan organik dalam meningkatkan kesuburan tanah}

Sesungguhnya petani kelompok mitra sudah mengetahui tentang peranan bahan organik dalam meningkatkan kesuburan tanah, tetapi terbatas hanya pada pupuk kandang saja. Petani kelompok mitra yaitu kelompok tani Gelugur Jaya dan Kelompok tani Minang Membangun, ternyata menggunakan pupuk kandang dalam dosis yang cukup tinggi. Jika pupuk kandang tidak ada, maka mereka tidak akan menanam padi karena menurut mereka tanaman padi tidak akan bagus bila tidak diberi pupuk kandang. Padahal untuk mendapatkan pupuk kandang tidak mudah, dan sering menjadi masalah apabila hendak menanam cabe, sedangkan mereka tidak mengetahui sumber bahan organik lainnya.

\subsection{Pembuatan rumah kompos dan pembelian mesin chopper}

Masyarakat tani kelompok mitra telah memiliki tempat khusus dalam pengolahan kirinyuh dan limbah-limbah pertanian.Rumah kompos menjadi sarana penunjang dalam pengolahan kirinyuh dan limbah pertanian menjadi kompos. rumah kompos terdiri dari bangunan rumah yang sederhana tapi cukup kuat berukuran $4 \mathrm{~m} \mathrm{x}$ $4 \mathrm{~m}$. Fungsinya untuk tempat produksi kompos, fermentasi, menyimpan dan pelindung bagi alat dan mesin serta gudang. Masyarakat tani kelompok mitra juga telah memiliki mesin chopper yang disimpan di Rumah Kompos. Mesin chopper telah mempermudah masyarakat tani kelompok mitra yaitu Kelompok Tani Gelugur Jayadan Minang Membangun dalam memanfaatkan dan mengolah kirinyuh dan limbah pertanian seperti jerami padi, kulit kakao dan pupuk kandang menjadi pupuk organik melalui proses pengomposan.

\subsection{Pengetahuan dan keterampilan kelompok mitra dalam pemanfaatan dan pengolahan gulma kirinyuh dan limbah pertanian menjadi pupuk organik melalui proses pengomposan.}

Sebagaimana telah dikemukakan terdahulu, bahwa petani kelompok mitra tidak memanfaatkan bahan organik selain pupuk kandang, jadi keterampilan kelompok mitra dalam mengolah gulma kirinyuh dan limbah pertanian menjadi pupuk organik melalui proses pengomposan masih rendah. Hasil diskusi dengan petani kelompok mitra yaitu kelompok tani gelugur Jaya dan kelompok tani Minang Membangun menunjukkan bahwa belum ada yang memanfaatkan gulma kirinyuh dan limbah pertanian sebagai sumber bahan organik, termasuk untuk menggantikan pupuk kandang bagi tanaman padi.

Setelah dilakukan kegiatan sosialisasi, pengetahuan petani kelompok mitra mengenai pentingnya pemanfaatan dan pengolahan gulma kirinyuh fan limbah pertanian menjadi salah satu sumber pupuk organik alternatif untuk mengurangi aplikasi pupuk buatan, menjaga kelestarian lingkungan, dan meningkatkan produktifitas tanah dan hasil tanaman yang dibudidayakan menjadi bertambah. Petani 
di kelompok tani Gelugur Jaya dan Minang Membangun menjadi lebih paham bahwa selain pupuk kandang, gulam kirinyuh dan limbah pertanian seperti kulit kakao yang mempunyai unsur hara lebih tinggi dibanding pupuk kandang, dan jerami padi dapat dimanfaatkan sebagai sumber bahan organik. Dalam memanfaatkan limbah pertanian menjadi sumber bahan organik dalam bentuk pupuk organik, sebaiknya dikomposkan terlebih dahulu.

Dengan kegiatan sosialisasi yang sudah dilaksanakan serta demonstrasi cara pembuatan kompos yang telah diperagakan serta dilakukan oleh masyarakat kelompok tani Gelugur Jaya dan Minang Membangun, pengetahuan dan keterampilan petani kelompok mitra dalam mengolah limbah pertanian. Petani kelompok mitra telah memiliki pemgetahuan dan keterampilan dalam mengolah gulma kirinyuh dan limbah pertanian menjadi kompos. Masyarakat tani kelompok mitra mampu secara mandiri dalam mengolah kirinyuh dan limbah pertanian menjadi kompos yang akan menjadi sumber pupuk organik. Sehingga masyarakat tani di kelompok mitra dapat mengurangi pemanfaatan pupuk buatan dalam membudidayakan tanaman.

\subsection{Pengetahuan dan keterampilan kelompok mitra dalam melakukan aplikasi kompos kirinyuh dan limbah pertanian ke tanah.}

\section{Untuk membuktikan kepada} khalayak sasaran (masyarakat tani kelompok mitra) manfaat dari penggunaan teknologi dalam pemanfaatan gulma kirinyuh dan limbah pertanian yang telah menjadi pupuk organik berupa kompos, maka dibuat demo pengaplikasian langsung ke tanah. Setelah kompos kirinyuh dan limbah pertanian yang dibuat matang, masyarakat tani kelompok mitra melakukan aplikasi kompos ke tanah, kemudian kompos diinkubasi selama 1 minggu. Pengetahuan dan keterampilan masyarakat tani kelompok mitra dalam melakukan aplikasi kompos ke tanah menjadi bertambah setelah dilakukan demonstrasi cara di lahan. Masyarakat tani kelompok tani Gelugur Jaya dan Minang Membangun mampu secara mandiri melakukan aplikasi kompos yang berasal dari campuran kirinyuh dan limbah pertanian ke tanah

\subsection{Pengetahuan dan keterampilan kelompok mitra dalam budidaya tanaman padi dengan pemanfaatan gulma kirinyuh dan limbah pertanian}

Pemanfaatan pupuk organik dari gulma kirinyuh dan limbah pertanian kulit kakao dan jerami padi serta pupuk kandang dalam budidaya tanaman padi membuka pengetahuan dan keterampilan masyarakat tani kelompok mitra. Sebelumnya masyarakat tani kelompok mitra hanya mengetahui dan memanfaatkan pupuk kandang sebaga sumber bahan organik alternatif untuk budidaya tanaman padi. Sementara untuk mendapatkan pupuk kandang dalam jumlah yang banyak tidak mudah dan sering menjadi masalah apabila hendak menanam padi. Setelah dilakukan kegiatan PKM ini, pengetahuan dan keterampilan masyarakat tani dari kelompok tani Gelugu Jaya dan kelompok tani Minang Membangun mengenai sumber bahan organik alternatif yang dapat digunakan sebagai pupuk organik menjadi bertambah. Masyarakat tani kelompok mitra telah mengetahui bahwa gulma kirinyuh dan begitu banyak limbah limbah pertanian yang dapat dijadikan pupuk organik selain pupuk kandang. Demikian juga dengan keterampilan masyarakat tani kelompok mitra juga bertambah dalam mengolah kirinyuh da limbah pertanian tersebut menjadi kompos, dan mengaplikasikannya ke tanah. Jadi, dalam membudidayakan tanaman padi, masyarakat tani kelompok mitra tidak khawatir lagi apabila ketersediaan pupuk kandang kurang. Karena masyarakat tani kelompok mitra dapat menggunakan 
kirinyuh dan limbah pertanian untuk sumber bahan organik yang dapat dijadikan pupuk organik melalui teknik pengomposan.

\subsection{Pengetahuan kelompok mitra mengenai dampak pembuangan limbah pertanian terhadap lingkungan}

Melalui sosialisasi dan presentasi yang dilakukan, pengetahuan masyarakat tani kelompok mitra mengenai dampak pembuangan limbah pertanian menjadi terbuka dan bertambah. Limbah organik yang menumpuk dilahan pertanian sebagian dibakar. Pembakaran akan meningkatkan global warming dan mencemari lingkungan. Melalui penyuluhan yang telah dilakukan, masyarakat tani kelompok mitra tidak kembali membakar limbah pertanian (organik).

\subsection{Hasil Analisis Hara Kompos}

Ciri kimia kompos dari kirinyuh dan limbah pertanian meliputi $\mathrm{pH}, \mathrm{C}$-organik, N, P, K dapat dilihat pada Tabel 1.

Tabel 1. Ciri kimia kompos dari kirinyuh dan limbah pertanian

\begin{tabular}{ccc}
\hline Ciri Kimia & Satuan & Nilai \\
\hline $\mathrm{pH}$ & - & 5,80 \\
C-organik & $\%$ & 18,45 \\
$\mathrm{~N}$-total & $\%$ & 1,22 \\
$\mathrm{C} / \mathrm{N}$ & - & 15,12 \\
$\mathrm{P}$ & $\%$ & 0,57 \\
$\mathrm{~K}$ & $\%$ & 1,65 \\
\hline
\end{tabular}

IV. KESIMPULAN DAN SARAN
1. Masyarakat tani kelompok mitra yaitu kelompok Gelugur Jaya dan kelompok tani Minang membangun sudah mengetahui tentang peranan bahan organik dalam meningkatkan kesuburan tanah tetapi terbatas hanya pada pupuk kandang saja

2. Masyarakat tani kelompok mitra belum mengetahui tentang pemanfaatan gulma kirinyuh dan limbah pertanian sebagai sumber bahan organik, termasuk untuk menggantikan pupuk kandang pada budidaya tanaman padi

3. Pengetahuan dan keterampilan masyarakat tani kelompok mitra bertambah dalam pemanfaatan dan pengolahan gulma kirinyuh dan limbah pertanian menjadi pupuk organik melalui proses pengomposan.

4. Masyarakat tani kelompok mitra sangat respon dan antusias dalam mengikuti semua kegiatan percontohan mulai dari mengumpulkan gulma kirinyuh dan limbah pertanian, mencincang kirinyuh dan limbah pertanian dengan mesin chopper, membuat kompos dari kirinyuh dan limbah pertanian, pengapikasian kompos dari limbah pertanian ke tanah, budidaya tanaman padi..

\section{DAFTAR PUSTAKA}
Deptan, 2010. Harga Pupuk. www.deptan.go.idDiakses 5 Juni 2016
Deptan, 2012. Harga Pupuk. www.deptan.go.id Diakses 5 Juni 2016

Didiek H.G dan A. Yufnal. 2006. Aktivator Pengomposan. Pengembangan Hasil Penelitian Unit Penelitian Bioteknologi Perkebunan. Bogor. 
Jamilah, Munir, R., Suardi, Mulyati, R., dan Renor, Y. 2009. Peranan Kesesuian Bioaktivator Untuk Meningkatkan Kandungan Basa-Basa Pada Kompos Guano dan c. Odorata. Jurnal Embrio. 2 (1): 19-25.

Panjaitan, S., R. S. Wahyuningtyas, dan D. Ambarawati. 2011. Pengaruh Naungan Terhadap Proses Ekofisiologi dan Pertumbuhan Shorea selanica (DC.) Blume di Persemaian. Jurnal Penelitian Dipterokarpa. 5(2): 73--82

Suwahyono, U. 2004. Cara Cepat Buat Kompos Dari Limbah. Penebar Swadaya. Jakarta. 